\title{
Faktor-Faktor Tingkat Kelulusan Uji Sertifikasi Keahlian Akuntansi Dasar
}

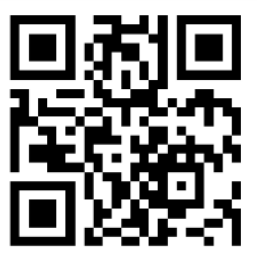

Nur Azmi Kolbi ${ }^{1}$, Aniek Wijayanti², Andy Setiawan ${ }^{3}$

DOI: https://doi.org/10.36339/jaspt.v4i2.333

\section{Abstrak}

Penelitian dilakuan agar dapat mengetahui mengenai pengaruh antara motivasi dan metode pembelajaran dengan tingkat kelulusan Uji Sertifikasi Keahlian Dasar Akuntansi (USKAD). Pada penelitian ini motivasi diukur dengan variabel yaitu, motivasi prestasi, motivasi karir, motivasi kualitas dan motivasi belajar. Populasi pada penelitian ini merupakan mahasiswa Akuntansi S1 UPNVJ pengambilan sampel yang digunakan pada penelitian menggunakan metode purposive sampling yaitu pada mahasiswa yang telah mengikuti USKAD dengan jumlah responden sebanyak 80 orang. Data dikumpulkan menggunakan kuesioner dan diolah dengan menggunakan SPSS 25. Hasil pada penelitian ini menunjukan bahwa motivasi prestasi, motivasi karir, motivasi kualitas dan motivasi belajar tidak memiliki pengaruh yang signifikan pada tingkat kelulusan USKAD. Metode pembelajaran secara signifikan berpengaruh terhadap tingkat kelulusan USKAD.

Universitas Pembangunan Nasional Veteran Jakarta Jl. RS. Fatmawati Raya, Pd. Labu, Kec. Cilandak, Kota Depok, Jawa Barat 12450

Kata Kunci: Motivasi, metode pembelajaran, kelulusan Uji Sertifikasi Keahlian Akuntansi Dasar

\section{Abstract}

The research was conducted aimed to determine the effect of motivation and learning methods on the graduation level of the Basic Accounting Skills Certification Test (USKAD). In this study motivation is measured by variables of, achievement motivation, career motivation, quality motivation and learning motivation. The population in this study is UPNVJ S1 Accounting students with sampling using a purposive sampling method, in students who have participated in USKAD with 80 respondents. Data were collected using a questionnaire and processed using SPSS 25. The results of this study indicate that achievement motivation, career motivation, quality motivation and learning motivation do not have a significant effect on USKAD graduation rates. The learning method significantly influences the level of USKAD graduation.

Keywords: motivation, learning motivation, graduation level of the Basic Accounting Skills Certification Test (USKAD)

JAS-PT

JURNAL ANALISIS SISTEM PENDIDIKAN TINGGI

ISSN $2580-5339$ elSSN $2620-5718$ Volume 4 Nomor 2 DESEMBER 2020 Hal $109-124$

FORUM DOSEN INDONESIA 


\section{PENDAHULUAN}

Indonesia dengan negara lainnya yang tergabung di ASEAN, membentuk Masyarakat Ekonomi ASEAN (MEA). Hal ini membawa konsekuensi bagi Indonesia untuk dapat menghasilkan lulusan sarjana yang memiliki standar Internasional agar dapat bekerja dan bersaing dengan tenaga kerja asing. Sejak diberlakukannya MEA di Indonesia pada 2016, seorang akuntan Indonesia dapat bekerja di negara ASEAN dengan bebas, begitu pula seorang akuntan dari Warga Negara Asing (WNA) yang tergabung dalam MEA juga dapat bekerja dengan bebas di Indonesia. Agar dapat bersaing seorang akuntan harus memiliki kemampuan yang kompeten, namun juga agar dapat menjadi seorang akuntan yang kompeten, diperlukannya syarat-syarat selain pendidikan formal pada universitas dan juga pendidikan non formal yaitu dengan pelatihan, pendidikan lanjutan ataupun sertifikasi (Hariyani, 2013).

Guna mempersiapkan lulusan sarjana menghadapi MEA, di beberapa perguruan tinggi telah mempersiapkan Lembaga Sertifikasi Profesi (LSP) dan melakukan kerjasama dengan Lembaga Professional lain seperti lkatan Akuntansi Indonesia (IAI), Microsoft, Zahir, Lembaga Pendidikan dan Pelatihan Perpajakan (LPP). Lembaga ini dibentuk sebagai upaya perguruan tinggi untuk menciptakan lulusan sarjana yang kompeten di bidangnya. Menurut "Peraturan Presiden Nomor 8 tahun 2012 mengenai Kerangka Kualifikasi Nasional Indonesia (KKNI)" Sertifikasi Kompetensii Kerja merupakan suatu pengakuan kepada tenaga kerja yang memiliki pengetahuan, keterampilan serta perilaku kerja sesuai dengan standar kompetensi kerja yang telah diaturkan, dengan demikian sertifikasi kompetensi menentukan bahwa tenaga kerja (pemilik setifikasi) tersebut terjamin akan kredibilitasnya dalam melaksanakan suatu pekerjaan yang menjadi tugas dan tanggung jawabnya. Terdapat beberapa uji sertifikasi kompetensi di bidang akuntansi antara lain, Ujian Sertifikasi Keahlian Akuntansi Dasar (USKAD), sertifikasi perpajakan, sertifikasi software akuntansi, teknisi akuntansi, Ujian Sertifikasi Ahli Akuntansi Pemerintahan (USAAP), Ujian kualifikasi Association of Chartered Certified Accountant (ACCA) dan lain sebagainya.

Berdasarkan data IAI (2016), tingkat kelulusan mahasiswa dalam ujian sertifikasi kompetensi akuntansi dasar masih dibawah 10 persen. Terdapat beberapa alasan mengapa tingkat kelulusan pada uji sertifikasi kompetensi sarjana Indonesia rendah dibandingkan dengan pekerja asing yaitu selain rendahnya penguasaan terhadap mesin berbasis teknologi canggih, juga dikarenakan kurangnya pemahaman mahasiswa mengenai sertifikasi kompetensi ataupun kurangnya motivasi pada mahasiswa itu sendiri untuk mengikuti uji kompetensi tersebut. Seharusnya mahasiswa dapat memahami bahwasannya dalam dunia kerja yang sudah memasuki MEA menuntut karyawan untuk memiliki keahlian khusus di bidangnya (Suherman, 2010).

Beberapa perguruan tinggi negeri memfasilitasi uji sertifikasi kompetensi untuk mahasiswanya, antara lain adalah Universitas Pembangunan Nasional Veteran Jakarta (UPNVJ) yang memfasilitasi berbagai uji sertifikasi kompetensi seperti Uji Sertifikasi Keahlian Dasar Akuntansi (USKAD), Brevet A\&B, zahir, Uji Teknisi Akuntansi. Tabel 1 berikut ini menunjukan data kelulusan mahasiswa Jurusan S1 Akuntansi.

JAS-PT

JURNAL ANALISIS SISTEM PENDIDIKAN TINGGI

ISSN $2580-5339$

eISSN $2620-5718$

Volume 4

Nomor 2

DESEMBER 2020

Hal $109-124$

FORUM DOSEN INDONESIA
Berdasarkan pada tabel 1 diatas sertifikasi yang tingkat kelulusannya masih rendah adalah USKAD. Oleh karena itu peneliti mengambil USKAD yang dimana tingkat kelulusannya masih terbilang rendah. USKAD bertujuan agar mahasiswa dapat menerangkan kerangka dasar penyusunan dan penyajian laporan keuangan sesuai dengan Standar Akuntansi Keuangan (SAK), serta dapat mengidentifikasi transaksi pada laporan keuangan. Berdasarkan latar belakang yang telah diuraikan peneliti tertarik untuk melakukan penelitian mengenai faktor-faktor tingkat kelulusan uji sertifikasi 
keahlian akuntansi dasar (USKAD) dengan menggunakan variabel motivasi dan metode pembelajaran sebagai variabel independennya.

Tabel 1 Peserta Sertifikasi Mahasiswa Jurusan S1 Akuntansi

\begin{tabular}{cccc}
\hline Sertifikasi & Jumlah peserta & Peserta Lulus & Persentase kelulusan \\
\hline USKAD & 285 & 88 & $30,8 \%$ \\
Zahir & 602 & 602 & $100 \%$ \\
Teknisi Akuntansi & 381 & 217 & $57,0 \%$ \\
Brevet A\&B & 281 & 261 & $68,5 \%$ \\
\hline
\end{tabular}

Sumber: Program Studi S1 Akuntansi, FEB, UPNVJ

Menurut IAI "Ujian Sertifikasi Keahlian Akuntansi Dasar (USKAD) merupakan ujian dalam mengukur kemampuan peserta dalam hal: memahami dan menjelaskan kerangka dasar penyusunan dan penyajian laporan keuangan sesuai dengan Standar Akuntansi Keuangan (SAK), mengidentifikasi transaksi yang terdapat dalam laporan keuangan, menyusun dan menyajikan laporan keuangan sesuai dengan siklus akuntansi dan menganalisa laporan keuangan". Tujuan Penelitian ini adalah Untuk memperoleh bukti yang empiris mengenai pengaruh motivasi dan metode pembelajaran terhadap tingkat kelulusan uji sertifikasi keahlian akuntansi dasar

\section{METODOLOGI PENELITIAN}

\section{Definisi Operasional dan Pengukuran Variabel}

Variable Dependen yang dipakai pada penelitian ini merupakan kelulusan USKAD di Universitas Pembangunan Nasional Veteran Jakarta. Berdasarkan data yang diperoleh dari UPNVJ mengenai kelulusan pada mahasiswa S1 Akuntasi masih dibawah lima puluh persen yang artinya masih belum mencapai setengah dari mahasiswa yang mengikuti ujian. Penelitian ini memakai tingkat kelulusan pada USKAD yang diukur dengan menggunakan dummy yaitu lulus $=1$ dan yang tidak lulus $=0$.

Variabel Independen $(X)$ dalam penelitian ini adalah :

\section{Motivasi Prestasi}

Prestasi dapat diartikan sebagai hasil yang memuaskan dari usaha pembelajaran untuk memotivasi seseorang mencapai cita-cita. Motivasi prestasi menunjukan kemampuan seseorang di bidangnya (Pratiwi, 2017). Motivasi prestasi juga dijelaskan dalam teori Mc Clelland (1953), bahwa orang yang berprestasi memiliki kekuatan dalam dirinya. Motivasi prestasi diukur dengan memakai item yang digunakan oleh Pratiwi (2017). dengan indikatornya berjumlah 3 pertanyaan. Penelitian ini memakai skala likert dengan skor sebagai berikut: a. Sangat Setuju (SS) dengan skor 4, b. Setuju (S) dengan skor 3, c. Tidak Setuju (TS) dengan skor 2, d. Sangat Tidak Setuju (STS) dengan skor 1. Indikator yang digunakan bersumber dari Pratiwi, 2017 yaitu: berprestasi lebih baik dari yang lain, dapat menyelesaikan beban pekerjaan yang diberikan dengan baik, serta mampu meningkatkan prestige dimasyarakat.

Motivasi prestasi dapat meningkatkan minat mahasiswa dalam mengikuti uji sertifikas, dengan adanya minat mahasiswa mengikuti uji sertifikasi dapat meningkatkan tingkat kelulusan dalam uji sertifikasi. Oleh karena itu motivasi prestasi dapat menjadi salah satu faktor tingkat kelulusan pada uji sertifikasi keahlian akuntansi dasar, karena jika seorang mahasiswa lulus dalam uji sertifikasi dapat dikatakan sebagai prestasi dalam dirinya. Berdasarkan uraian diatas, maka peneliti merumuskan hipotesis:

$\mathrm{H}_{1}$ : Motivasi Prestasi berpengaruh positif terhadap Kelulusan USKAD

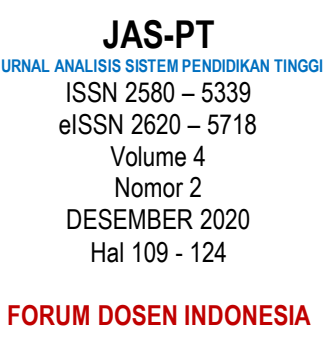




\section{Motivasi Karir}

Motivasi karir merupakan kekuatan atau keinginan yang berasal dalam diri seseorang untuk meningkatkan kemampuannya dalam pencapai karir yang di inginkannya, kemudian mengembangkan potensi agar lebih baik dari sebelumnya (Ulfah, 2019). Karir juga dapat diartikan sebagai rangkaian perjalanan kerja seseorang dalam mencapai tujuan pekerjaannya (Dyastari dan Yadnyana, 2016). Motivasi karir diukur dengan memakai item yang digunakan oleh (Widyastuti, 2004) dan Kusuma (2011) dengan indikatornya berjumlah 5 pertanyaan. Penelitian ini memakai skala likert dengan skor sebagai berikut: a. Sangat Setuju (SS) dengan skor 4, b. Setuju (S) dengan skor 3, c. Tidak Setuju (TS) dengan skor 2, d. Sangat Tidak Setuju (STS) dengan skor 1. Indikator yang digunakan bersumber dari Widyastuti (2004), Solikhah (2014), dan Kusuma (2016) yaitu: Pengakuan profesionalitas, kesempatan bekerja di perusahaan bonafit, mendapatkan gaji pertama yang lebih tinggi, menikmati hidup yang lebih berkualitas, serta dapat memperluas peluang pekerjaan.

Penelitian Indirani didukung oleh penelitian Pratiwi (2017) bahwa tidak adanya pengaruh signifikan anatara motivasi karir terhadapi minat mahasiswai iakuntansi mendapatkan sertifikasi Chartered Accountant (CA), dikarenakan bahwa rata-rata mahasiswa belum terlalu mengetahui dengan baik dunia kerja dan karir secara nyata dan beranggapan bahwa dapat berkarir bukan hanya dunia akuntansi saja. Berbeda pada penelitian yang dilakukan Kusuma (2011) mengemukakan bahwa adanya pengaruh pengembangan karir pada minat mahasiswa dalam mengikuti Pendidikan Profesi Akuntansi (PPAk), dalam penelitiannya mengindikasi yaitu pada mahasiswa yang mengikuti PPAk menginginkan berkarir sebagai akuntan publik. Berdasarkan uraian diatas, maka peneliti merumuskan hipotesis:

$\mathrm{H}_{2}$ : Motivasi Kualitas berpengaruh positif terhadap Kelulusan USKAD

\section{Motivasi Kualitas}

Motivasi kualitas merupakan keinginan yang timbul pada diri seseorang untuk meningkatkan derajat diri mereka dengan hal yang berkualitas seperti menambah segala sesuatu pengetahuan (Angger, 2014). Motivasi kualitas diukur dengan memakai item yang digunakan Widya (2004) dengan indikatornya berjumlah 5 pertanyaan. Penelitian ini memakai skala likert dengan skor sebagai berikut: a. Sangat Setuju (SS) dengan skor 4, b. Setuju (S) dengan skor 3, c. Tidak Setuju (TS) dengan skor 2, d. Sangat Tidak Setuju (STS) dengan skor 1.

Indikator yang digunakan bersumber dari Widyastuti (2004) yaitu: Meningkatkan Keahlian dalam pengaplikasian ilmu dalam kehidupan sehari-hari, dapat menyusun laporang keuangan sesuai dengan siklus akuntansi, meningkatkan kemampuan mengenai Akuntansi Dasar sesuai dengan SAK, dapat menganalisa laporan keuangan dengan baik, meningkatkan pengetahuan menganai Akuntansi Dasar dan pengaruhnya terhadap keputusan keuangan dan manajerial.Jika seseorang memiliki motivasi kualitas dalam dirinya maka minat dalam mengikuti uji sertifikasi akan meningkat. Seseorang beranggapan bahwa jika mereka mengikuti uji serifikasi dapat meningkatkan kualitas dalam dirinya Sehingga orang tersebut akan terus berusaha dengan demikian diduga

JAS-PT

JURNAL ANALISIS SISTEM PENDIDIKAN TINGG ISSN $2580-5339$ eISSN $2620-5718$

Volume 4 Nomor 2 DESEMBER 2020 Hal $109-124$

FORUM DOSEN INDONESIA tingkat kelulusan juga akan dapat meningkat. Jadi berdasarkan uraian diatas dapat diajukan hipotesis sebagai berikut:

$\mathrm{H}_{3}$ : Motivasi Kualitas berpengaruh positif terhadap Kelulusan USKAD

\section{Motivasi Belajar}

Motivasi belajar merupakan keinginan untuk mahasiswa agar belajar untuk mecapai suatu tujuan dengan hasil yang maksimal (Astasari, 2018). Hamzah (2007) dalam 
(Astasari, 2018) menyatakan bahwa jika seseorang memiliki keinginan yang tinggi pada motivasi belajar maka hasil belajar yang didapat akan tinggi pula.

Motivasi belajar diukur dengan memakai item yang digunakan (Hamzah 2007) dengan indikatornya berjumlah 6 pertanyaan. Penelitian ini memakai skala likert dengan skor sebagai berikut: a. Sangat Setuju (SS) dengan skor 4, b. Setuju (S) dengan skor 3, c. Tidak Setuju (TS) dengan skor 2, d. Sangat Tidak Setuju (STS) dengan skor 1. Indikator yang digunakan bersumber dari Hamzah (2007) yaitu: Senang mengerjakan tugas akuntansi dan keuangan, berusaha untuk mengerjakan apabila mengalami kesulitan, bertanya kepada dosen ataupun teman yang lebih paham, dengan berlatih membantu dalam mengerjakan USKAD, meluangkan waktu 2-3 jam untuk berlajar dan mengulang materi, mengorbankan apapun demi kelancaran dalam belajar.

Penelitian yang dilakukan Yusuf (2009) mengemukakan bahwa motivasi belajar terdapat pengaruh positif terhadap hasil belajar yang artinya dengan peningkatan motivasi belajar akan mampu mempengaruhi hasil belajar penelitian, tersebut didukung oleh Safaat (2016), oleh karena itu jika semakin tinggi motivasi belajar dalam diri seseorang maka hasil yang didapatkan akan semakin baik begitu pula dengan kelulusan pada uji sertifikasi karena jika semakin termotivasi seseorang dalam belajar maka diduga tingkat kelulusan juga akan dapat meningkat. Sehingga berdasarkan uraian diatas dapat diajukan hipotesis sebagai berikut:

\section{$\mathrm{H}_{4}$ : Motivasi Belajar berpengaruh positif terhadap Kelulusan USKAD}

\section{Metode Pembelajaran}

Metode pembelajaran studi kasus merupakan metode yang digunakan untuk membantu mahasiwa dalam mendapat informasi, ide, kemampuan, nilai, cara berfikir, dan sarana untuk mahasiswa dapat mengapresiasikan dirinya dan cara-cara bagaimana belajar (Weil, 2002). Menurut Menurut Accounting Education Change Commission (AECC, 1990) studi kasus merupakan pengajaran akuntansi yang inovatif. Pembelajaran langsung: menurut Killen dalam Depdiknas (2010) mengacu pada berbagai cara pembelajaran ekspositori (pemindahan pengetahuan dari pengajar kepada mahasiswa secara langsung), misalnya melalui ceramah, demonstrasi, dan tanya jawab yang melibatkan seluruh kelas, dalam hal ini penyampaian materi disampaikan secara terstruktur dan memfokuskan pada capaian akademik.

Metode pembelajaran diukur dengan memakai item yang digunakan (Weil, 2002) dengan indikatornya berjumlah 14 pertanyaan. Penelitian ini memakai skala likert dengan skor sebagai berikut: a. Sangat Setuju (SS) dengan skor 4, b. Setuju (S) dengan skor 3, c. Tidak Setuju (TS) dengan skor 2, d. Sangat Tidak Setuju (STS) dengan skor 1. Indikator yang digunakan bersumber dari Weil, (2004), Wardhani, (2017) yaitu: Menggunakan studi kasus dapat mengembangkan kemampuan menganalisis dan memecahkan masalah, studi kasus dapat mengembangkan pemahaman dalam Akuntansi Keuangan, studi kasus dapat membangun sikap kritis, dengan studi kasus lebih menyenangkan, studi kasus lebih efektif, studi kasus lebih mudah dipahami, pembekalan yang diberikan IAI membantu persiapan USKAD, pembekalan dari IAI sangat cukup untuk memahami USKAD, soal latihan yang diberikan sangat relevan, pembelajaran di LAB membantu memahami USKAD, pengajar di LAB membantu memahami USKAD, soal latihan di LAB relevan, sebaiknya USKAD diadakan setelah menyelesaikan mata kuliah Akuntansi yang berhubungan dengan USKAD.

Penggunaan metode pembelajaran dengan studi kasus serta pembelajaran secara langsung mempermudah mahasiswa dalam memahami dan memecahkan suatu masalah yang diberikan, jika semakin mudah mahasiswa dalam memahami sebuah

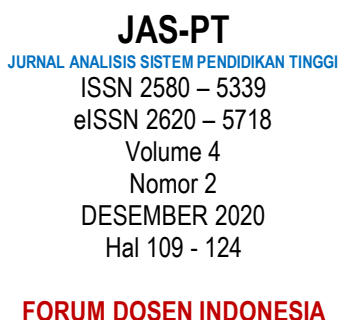

ANALISIS SISTEM PENDIDIKAN TINGGI ISSN $2580-5339$ SN $2620-5718$ Nomor 2 DESEMBER 2020 FORUM DOSEN INDONESIA 
kasus maka akan semakin mudah pula mahasiswa dalam mengisinya dengan demikian diduga tingkat kelulusan juga akan dapat meningkat pada uji sertifikasi. Sehingga berdasarkan uraian diatas dapat diajukan hipotesis sebagai berikut:

$\mathrm{H}_{5}$ : Metode Pembelajaran berpengaruh positif terhadap Kelulusan USKAD

\section{Populasi, Sampel dan Metode}

Populasi pada penelitian yaitu mahasiswaa akuntansi S1 yang telah mengikuti USKAD. Adapun sampel diambil adalah mahasiswaa akuntansi S1 yang telah mengikuti USKAD sebanyak 285 orang. Teknik pengambilan sampel menggunakan metode purpose sampling, yaitu metode sampling dengan menentukan kriteria yang sesuai dengan tujuan tertentu (Sugiyono, $2016 \mathrm{hlm}$. 85). Pada penelitian ini untuk menentukan jumlah sampel menggunakan rumus slovin, dengan hasil perhitungannya sebagai berikut:

Keterangan:

$$
n=\frac{N}{N \cdot e^{2}+1}=\frac{285}{285 \cdot 0 \cdot 1^{2}+1}=74,02
$$

$\mathrm{n}=$ jumlah sampel, $\mathrm{N}=$ jumlah populasi, $e^{2}=$ batas ketelitian yang diinginkan

Dari hasil perhitungan diatas diperoleh jumlah sampel dalam penelitian ini minimal sebanyak 74 mahasiswa. Jenis data yang digunakan ialah data primer, yaitu sumber data yang didapatkan atau di peroleh dari pihak pertama (Supriono, 2016). Data diperoleh dengan menyebar kuisioner yang berisi pertanyaan-pertanyaan yang mewakili indikator.

\section{Teknik Analisis Data.}

Pada penelitian ini menggunakan berbagai pengujian terhadap model dengan data. Pada pengumpulan data yaitu dengan melakukan penyebaran kuesioner kepada mahasiswa dan teknik dalam menganalisis data yaitu menggunakan statistik deskriptif lalu untuk menguji kualitas data menggunakan uji validitas dan reliabilitas serta uji multikolonieritas dan untuk menguji model menggunakan uji keseluruhan model, uji kelakayan model serta uji koefisien determinasi dan pengujian hipotesis menggunakan uji wald. Model Regesi pada penelitian menggunakan model regresi logistik, yang dapat dinyatakan dengan persamaan sebagai berikut:

Keterangan:

$$
\operatorname{LUS}\left(\frac{p}{1-p}\right)=\alpha+\beta 1 \text { PRES }+\beta 2 K A R+\beta 3 \mathrm{KUA}+\beta 4 \mathrm{BEL}+\beta 5 \mathrm{MET}+\mathrm{e}
$$

LUS $\left(\frac{p}{1-p}\right)=$ Kelulusan USKAD dengan variabel dummy dimana $1=$ lulus $0=$ tidak lulus, $\alpha=$ konstanta, $\beta 1-\beta 6=$ koefisien regresi, PRES $=$ Motivasi Prestasi, KAR = Motivasi Karir, $\mathrm{KUA}=$ Motivasi Kualitas, $\mathrm{BEL}=$ Motivasi Belajar, $\mathrm{MET}=$ Metode pembelajaran studi kasus

$\mathrm{e}=$ residual eror

\section{HASIL DAN PEMBAHASAN}

\section{Deskripsi Objek Penelitian}

JAS-PT

JURNAL ANALISIS SISTEM PENDIDIKAN TINGG

ISSN $2580-5339$ eISSN $2620-5718$

Volume 4

Nomor 2

DESEMBER 2020

Hal $109-124$

FORUM DOSEN INDONESIA
Data dalam penelitian ini merupakan data primer serta yang menjadi objek penelitian adalah mahasiswa akuntansi UPNVJ tahun 2015-2016 yang telah mengikuti USKAD. Kuesioner disebarkan melalui google form yang di sebarkan melalui grup angkatan. Dengan jumlah responden yang mengikuti USKAD sebanyak 285 orang dan yang mengisi sebanyak 80 orang, semua kuesioner yang dikembalikan dapat diolah. Dari 80 kuesioner sebanyak 20 orang merupakan angkatan 2015 dan sisanya yaitu sebanyak 60 orang merupakan angkatan 2016. 


\section{Deskripsi Data Penelitian}

Deskripsi data penelitian digunakan untuk menjelaskan data dari masing-masing variabel dengan menggunakan hasil statistik deskriptif. Deskriptif statistik merupakan interpretasi variabel yang sudah lolos uji kualitas data (uji validitas dan reliabilitas)

\section{Deskripsi Kelulusan Uskad}

Peserta dinyatakan lulus apabila mendapatkan nilai 70 , peneliti menyebar kuesioner melalui group angkatan 2015 dan 2016 dengan total yang mengikuti uskad sebanyak 285 orang, terdapat 80 orang yang mengisi kuesioner. Dari 80 kuesioner sebanyak 20 orang merupakan angkatan 2015 dari 20 orang 11 diantaranya tidak lulus uskad dan sisanya 9 lulus uskad dan sebanyak 60 orang merupakan angkatan 2016. Pada angkatan 2016 jumlah yang lulus sama dengan jumlah yang tidak lulus yaitu sebanyak 30 yang lulus dan 30 yang tidak lulus.

Analisis Statistik Deskiptif

Tabel 2. Hasil Uji Statistik Deskriptif

\begin{tabular}{lccccc}
\hline \multicolumn{1}{c}{ Variabel } & N & Min & Max & Mean & Std.Dev \\
\hline Motivasi Prestasi & 80 & 2 & 4 & 3.22 & 0.403 \\
\hline Motivasi Karir & 80 & 1 & 4 & 3.11 & 0.447 \\
\hline Motivasi Kualitas & 80 & 2 & 4 & 3.21 & 0.460 \\
\hline Motivasi Belajar & 80 & 1 & 4 & 2.93 & 0.358 \\
\hline Metode & 80 & 1 & 4 & 2.86 & 0.221 \\
Pembelajaran & & & & &
\end{tabular}

Sumber: Data Primer Diolah

Dapat dilihat pada data tabel 2 diatas menggambarkan bahwa mean pada motivasi prestasi sebesar 3.22 dengan jumlah item pertanyaan sebanyak 3 dan standar deviasi sebesar 0.403 dari 80 responden. Mean pada motivasi karir sebesar 3.11 dengan jumlah item pertanyaan sebanyak 5 dan standar deviasi sebesar 0.447 dari 80 responden. Mean pada motivasi kualitas sebesar 3.21 dengan jumlah item pertanyaan sebanyak 5 dan standar deviasi sebesar 0.460 dari 80 responden. Mean pada motivasi belajar sebesar 2.93 dengan jumlah item pertanyaan sebanyak 6 dan standar deviasi sebesar 0.358 dari 80 responden. Mean pada motivasi karir sebesar 2.86 dengan jumlah item pertanyaan sebanyak 5 dan standar deviasi sebesar 0.221 dari 80 responden.

Kesimpulan dari nilai mean dan standar deviasi pada penelitian ini dapat dilihat bahwa pada penelitian yang dilakukan tidak terdapat perbedaan yang cukup besar dari responden. Hal ini dikarenakan seluruh nilai mean > dari standar deviasi yang artinya menunjukan tingkat homogenitas data yang cukup tinggi dan menunjukan adanya ratarata yang dapat menggambarkan data sesungguhnya.

Uji Multikolonieritas

Tabel 3. Hasil Uji Multikolonieritas

\begin{tabular}{lcc}
\hline \multicolumn{1}{c}{ Model } & \multicolumn{2}{c}{ Collinearity Statistics } \\
\cline { 2 - 3 } 1 (Constant) & Tolerance & VIF \\
\hline PRES & & 2.655 \\
\hline KAR & 0.377 & 2.283 \\
\hline KUA & 0.438 & 1.609 \\
\hline BEL & 0.622 & 1.629 \\
\hline MET & 0.614 & 1.520 \\
\hline
\end{tabular}

Sumber: Data Primer Diolah

JAS-PT

JURNAL ANALISIS SISTEM PENDIDIKAN TINGG| ISSN $2580-5339$ eISSN 2620 - 5718 Volume 4 Nomor 2 DESEMBER 2020 Hal 109 - 124 
Hasil uji multikolonieritas menunjukan pada setiap variabel nilai VIF $<10$ dan nilai tolerance $>0.10$ yang artinya tidak terlihat adanya gejala multikolonieritas pada varibel, sehingga dapat digunakan sebagai penilaian pada instrument penelitian selanjutnya.

Uji Keseluruhan Model (Overall Fit Model Test)

Tabel 4. Hasil -2 Log Likelihood Block Number = 0

\begin{tabular}{cccc}
\hline \multicolumn{2}{c}{ Iteration } & $\mathbf{- 2}$ Log likelihood & Coefficients Constant \\
\hline Step 0 & 1 & 110.854 & 0.50 \\
\cline { 2 - 4 } & 2 & 110.854 & 0.50 \\
\hline
\end{tabular}

Sumber: Data Primer Diolah

Tabel 5. Hasil -2 Log Likelihood Block Number = 0

\begin{tabular}{llllccccc}
\hline \multirow{2}{*}{ Iteration } & \multicolumn{2}{c}{$\mathbf{- 2}$ Log } & \multicolumn{7}{c}{ Coefficients } \\
& & likelihood & Constant & X1 & X2 & X3 & X4 & X5 \\
\hline \multirow{3}{*}{ Step } & 1 & 97.315 & -9.675 & 0.238 & 0.174 & -0.197 & 0.087 & 0.155 \\
\cline { 2 - 9 } & 2 & 96.920 & -11.557 & 0.272 & 0.210 & -0.248 & 0.116 & 0.087 \\
\cline { 2 - 9 } & 3 & 96.917 & -11.704 & 0.275 & 0.214 & -0.252 & 0.118 & 0.189 \\
\cline { 2 - 8 } & 4 & 96.917 & -11.705 & 0.275 & 0.214 & -0.252 & 0.118 & 0.189 \\
\hline
\end{tabular}

Sumber: Data Primer Diolah

Tabel 6. Hasil -2 Log Likelihood Block Number = 0

\begin{tabular}{lr}
\hline & -2 Log Likelihood \\
\hline-2 Log Likelihood Block Number $=0$ & 110.854 \\
\hline-2 Log Likelihood Block Number $=1$ & 96.917 \\
\hline
\end{tabular}

\section{Sumber: Data Primer Diolah}

Berdasarkan hasil uji keseluruhan model pada data diatas menggambarkan bahwa nilai -2Log Likehood block number $=0>$ nilai -2 Log likelihood block number $=1$ dimana nilai -2Log Likehood block number $=0$ sebesar 110.854 dan nilai -2 Log Likehood block number $=1$ sebesar 96.917, terdapat penurunan nilai sebesar 13.937 yang artinya bahwa dengan adanya tambahan pada variabel independent ke dalam model mampu memperbaiki keseluruhan model fit serta menunjukan model regresi yang baik.

Uji Kelayakan Model (Hosmer and Lemeshow Test)

Tabel 7. Hasil Hosmer and Lemeshow Test

\begin{tabular}{lccc}
\hline Step & Chi-square & df & Sig. \\
\hline 1 & 10.842 & 8 & 0.211 \\
\hline
\end{tabular}

Sumber: Data Primer Diolah

Data di atas menunjukan bahwa nilai Hosmer and Lemeshow Test sebesar 10.842 dengan probabilitas signifikansi $>0.05$ yaitu sebesar 0.211 . dapat disimpulkan bahwa model mampu memprediksi nilai observasi sehingga model ini dapat digunakan untuk analisis selanjutnya.

Koefisien Determinasi (Nagelkerke's $R$ Square)

JAS-PT

JURNAL ANALISIS SISTEM PENDIDIKAN TINGG

ISSN $2580-5339$ elSSN $2620-5718$

Volume 4

Nomor 2

DESEMBER 2020

Hal $109-124$

FORUM DOSEN INDONESIA

Tabel 8. Hasil Uji Koefisien Determinasi

\begin{tabular}{lccc}
\hline Step & -2 Log likelihood & Cox \& Snell R Square & Nagelkerke R Square \\
\hline 1 & 96.917 & 0.160 & 0.213
\end{tabular}

Sumber: Data Primer Diolah

Nilai Nagelkerke's $R$ Square sebesar 0.213 . Hal ini dapat disimpulkan bahwa variabel dependen yaitu tingkat kelulusan uskad dapat dijelaskan oleh variabel independen, yaitu 
motivasi prestasi, motivasi karir, motivasi kualitas, motivasi belajar dan metode pembelajaran sebesar $21,3 \%$ sedangkan sisanya sebesar $78,7 \%$ dijelaskan oleh variabel-variabel lain di luar penelitian.

\section{Uji Signifikansi Koefisien Regresi}

Tabel 9. Hasil Uji Wald

\begin{tabular}{llcccccc}
\hline & & B & S.E. & Wald & df & Sig. & Exp(B) \\
\hline Step 1a & PRES & 0.275 & 0.274 & 1.009 & 1 & 0.315 & 1.316 \\
\cline { 2 - 7 } & KAR & 0.214 & 0.154 & 1.923 & 1 & 0.166 & 1.238 \\
\cline { 2 - 7 } & KUA & -0.252 & 0.152 & 2.742 & 1 & 0.098 & 0.777 \\
\cline { 2 - 7 } & BEL & 0.118 & 0.140 & 0.714 & 1 & 0.398 & 1.125 \\
\cline { 2 - 7 } & MET & 0.189 & 0.095 & 3.963 & 1 & 0.047 & 1.209 \\
\cline { 2 - 7 } & Constant & -11.705 & 4.282 & 7.471 & 1 & 0.006 & 0.000 \\
\hline
\end{tabular}

Sumber: Data Primer Diolah

Hasil pada pengujian wald dapat terlihat pada tabel diatas variabel motivasi prestasi menunjukan nilai pada koefisien regresi positif sebesar 0.275 dan dengan nilai statistik waldnya sebesar 1.009 , serta dapat dilihat dengan nilai pada tabel chi-square untuk tingkat signifikansi $5 \%$ pada derajat bebas $=1$ diperoleh sebesar 3.841. yang artinya bahwa nilai wald hitung memiliki nilai lebih kecil dari chi-square yaitu sebesar $1.009<$ 3.841 dan pada nilai signifikan sebesar $0.315>0.05$. Dengan demikian Ho diterima dan $\mathrm{H} 1$ ditolak sehingga dapat disimpulkan bahwa motivasi prestasi secara parsial tidak berpengaruh terhadap kelulusan uskad.

Variabel motivasi karir menunjukan nilai pada koefisien regresii positif sebesar 0.214 dan dan dengan nilai statistik waldnya sebesar 1.923 , serta dapat dilihat dengan nilai tabel chi-square untuk tingkat signifikansi 5\% pada derajat bebas $=1$ diperoleh sebesar 3.841 . yang artinya bahwa nilai wald hitung memiliki nilai lebih kecil dari chi-square yaitui 1.923 $<3.841$ dan pada nilai signifikan sebesar $0.166>0.05$ Dengan demikian Ho diterima dan $\mathrm{H} 2$ ditolak sehingga dapat disimpulkan bahwa motivasi karir secara parsial berpengaruh tidak signifikan positif terhadap kelulusan uskad.

Variabel motivasi kualitas menunjukan nilai pada koefisien regresi negatif sebesar -0.252 dan nilai statistik waldnya sebesar 2.742 , serta dapat dilihat dengan nilai tabel chi-square untuk tingkat signifikansi $5 \%$ pada derajat bebas $=1$ diperoleh sebesar 3.841. yang artinya bahwa nilai wald hitung memiliki nilai lebih kecil dari chi-square yaitu $2.742<$ 3.841 dan pada nilai signifikan sebesar $0.098>0.05$. Dengan demikian Ho diterima dan $\mathrm{H} 3$ ditolak sehingga dapat disimpulkan bahwa motivasi kualitas secara parsial tidak berpengaruh terhadap kelulusan uskad.

Variabel motivasi belajar menunjukan nilai pada koefisien regresi positif sebesar 0.118 dan nilai statistik waldnya sebesar 0.714 , serta dapat dilihat dengan nilai tabel chi-square untuk tingkat signifikansi $5 \%$ pada derajat bebas $=1$ diperoleh sebesar 3.841. yang artinya bahwa nilai wald hitung lebih kecil dari chi-square yaitu $0.714<3.841$ dan pada nilai signifikan sebesar $0.398>0.05$. Dengan demikian Ho diterima dan H4 ditolak sehingga dapat disimpulkan bahwa motivasi belajar secara parsial tidak berpengaruh positif terhadap kelulusan uskad.

Variabel metode pembelajaran menunjukan nilai pada koefisien regresi positif sebesar 0.189 dan nilai statistik waldnya sebesar 3.963 , serta dapat dilihat dengan nilai tabel chisquare untuk tingkat signifikansi $5 \%$ pada derajat bebas = 1 diperoleh sebesar 3.841 . yang artinya bahwa nilaiwald hitung lebih kecil dari chi-square yaitu $3.963>3.841$ dan pada nilai signifikan sebesar $0.047<0.05$. Dengan demikian Ho ditolak dan H5 diterima

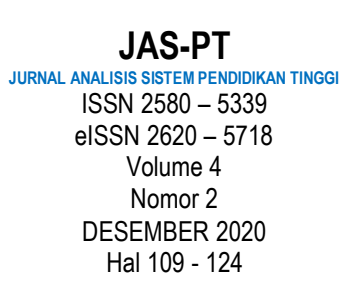

FORUM DOSEN INDONESIA 
sehingga dapat disimpulkan bahwa metode pembelajaran secara parsial berpengaruh signifikan terhadap kelulusan uskad.

\section{Analisis Regresi Logistik}

$$
\text { LUS }\left(\frac{p}{1-p}\right)=-11.705+0.275 \text { PRES + 0.214KAR - 0.252KUA + 0.118BEL + 0.189MET+e }
$$

Berdasarkan persamaan model regresi logistik di atas menjelaskan bahwa nilai konstanta sebesar -11.705 dan nilai $\operatorname{Exp(B)~sebesar~} 0.000$ memiliki arti bahwa apabila variabel motivasi prestasi, motivasi karir, motivasi kualitas, motivasi belajar, metode pembelajaran tetap atau konstan, maka log of odds atau probabilitas kemungkinan pada tingkat kelulusan uskad akan turun dengan faktor $0.000 e^{-11.705}$ ).

Variabel motivasi prestasi memiliki nilai koefisien B 0.275 dan $\operatorname{Exp}(\mathrm{B})$ 1.316. yang artinya tingkat kelulusan uskad pada mahasiswa yang memiliki motivasi prestasi, akan naik sebanyak 0.275 kali lipat dibandingkan dengan yang tidak ada motivasi prestasi dan log of odds atau probabilitas kemungkinan tingkat kelulusan uskad naik dengan faktor 1.316 $\left.e^{0.275}\right)$.

Variabel motivasi karir memiliki nilai koefisien B 0.214 dan Exp (B) 1.238 yang artinya tingkat kelulusan uskad pada mahasiswa yang memiliki motivasi karir, akan naik sebanyak 0.214 kali lipat dibandingkan dengan yang tidak ada motivasi karir dan log of odds atau probabilitas kemungkinan tingkat kelulusan uskad naik dengan faktor 1.238 $\left.e^{0.214}\right)$.

Variabel motivasi kualitas memiliki nilai koefisien B -0.252 dan Exp (B) 0.777 . yang artinya tingkat kelulusan uskad pada mahasiswa yang memiliki motivasi kualitas, akan turun sebanyak -0.252 dan log of odds atau probabilitas kemungkinan tingkat kelulusan uskad turun dengan faktor $0.777 e^{-0.252}$ ).

Variabel motivasi belajar memiliki nilai koefisien B 0.118 dan $\operatorname{Exp}(\mathrm{B}) 1.125$. yang artinya tingkat kelulusan uskad pada mahasiswa yang memiliki motivasi belajar, akan naik sebanyak 0.118 kali lipat dibandingkan dengan yang tidak ada motivasi belajar. dan log of odds atau probabilitas kemungkinan tingkat kelulusan uskad naik dengan faktor 1.125 $\left.e^{0.118}\right)$.

Variabel metode pembelajaran memiliki nilai koefisien B 0.189 dan Exp (B) 1.209. yang artinya tingkat kelulusan pada mahasiswa yang memiliki metode pembelajaran, akan naik sebanyak 0.189 kali lipat dibandingkan dengan yang tidak ada metode pembelajaran. dan log of odds atau probabilitas kemungkinan tingkat kelulusan uskad naik dengan faktor $1.209 e^{0.189}$ ).

\section{Pengaruh Motivasi Prestasi terhadap Kelulusan USKAD}

Pada hasil pengujian variabel motivasi prestasi menunjukan nilai signifikan sebesar 0.315 yang berarti $>0.05$. Nilai koefisien regresi positif sebesar 0.275 . Dengan demikian dapat disimpulkan bahwa motivasi prestasi tidak berpengaruh terhadap tingkat kelulusan uskad pada mahasiswa FEB di UPNVJ. Pada Penelitian yang telah dilakukan terdapat perbedaan dengan penelitian yang dikemukakan Abidin dan Ervanto (2015) yang menemukan hasil bahwa motivasi prestasi, motivasi karir, motivasi ekonomi terdapat

JAS-PT

JURNAL ANALISIS SISTEM PENDIDIKAN TINGG ISSN $2580-5339$ elSSN $2620-5718$

Volume 4 Nomor 2 DESEMBER 2020 Hal $109-124$ pengaruh signifikan terhadap minat mahasiswa mengikuti Certified Publik Accountant (CPA) dan penelitian yang dikemukakan oleh Pratiwi (2017) menyatakan adanya pengaruh anatara motivasi prestasi dengan minat mahasiswa akuntansi untuk memperoleh sertifikasi Chartered Accountant (CA), seseorang yang memiliki sertifikat CA di anggap masyarakat luas sebagai sebuah prestasi. 
Pada penelitian ini motivasi prestasi merupakan faktor internal atau faktor yang berasal dari dalam diri individu. Pada penelitian ini jumlah responden sebanyak 80 orang, 60 orang merupakan angkatan 2016 yang dinyakan lulus sebanyak 30 orang dan yang tidak lulus sebanyak 30 orang dan sisanya sebanyak 20 orang angkatan 2015 dengan yang dinyatakan lulus sebanyak 9 orang dan yang tidak lulus sebanyak 11 orang.

Pada penelitian menunjukan hasil pada pernyataan mengenai, bahwa sertifikasi membantu saya dalam menyelesaikan pekerjaan dengan lebih baik pada saat bekerja nanti. Dari sebanyak 20 orang yang telah lulus pada universitas, 9 orang dinyatakan lulus dalam uskad 4 orang diantaranya menyatakan tidak setuju bahwa sertifikasi membantu dalam menyelesaikan pekerjaan dengan lebih baik. Hal ini dikarenakan bahwa menurut Gesinde (2000) terdapati beberapa faktori yang mempengaruhii motivasi prestasi salah satunya yaitu, persepsi pribadi mengenai pribadinya dalam hal ini seseorang berpresepsi bahwa uskad bukan sebuah jaminan, mahasiswa akuntansi bisa menjadi lebih baik.

\section{Pengaruh Motivasi Karir terhadap Kelulusan USKAD}

Pada hasil pengujian variabel motivasi karir menunjukan nilai signifikan sebesar 0.166 yang berarti $>0.05$. Nilai koefisien regresi positif sebesar 0.214 . Dengan demikian dapat disimpulkan bahwa motivasi karir tidak berpengaruh terhadap tingkat kelulusan uskad pada mahasiswa FEB di UPNVJ. Penelitian yang telah dilakukan pada motivasi prestasi tidak sejalan dengan dengan penelitian yang telah dilakukan oleh Kusuma (2011) menyebutkan bahwa adanya pengaruh pengembangan karir terhadap minat mahasiswa agar mengikuti Pendidikan Profesi Akuntansi (PPAk), dalam penelitiannya mengindikasi bahwa mahasiswa yang mengikuti PPAk menginginkan berkarir sebagai akuntan publik, serta penelitian Kusuma (2011) didukung oleh Abidin dan Ervanto (2015) mengemukakan bahwa motivasi karir memiliki pengaruh terhadap minat mahasiswa akuntansi mengikuti ujian CPA

Penelitian ini sejalan dengan penelitian yang dilakukan oleh Indriani (2014) yang mengemukakan motivasi karir tidak adanya pengaruh signifikan, tehadap minat mahasiswa mengikuti PPAk.dalam penelitian ini menunjukan motivasi mahasiswa terhadap karir tinggi yaitu sebesar 3.11, tetapi pada pengujian hipotesis motivasi karir tidak adanya pengaruh terhadap tingkat kelulusan uskad. Hal ini di karenakan karir pada mahasiswa akuntansi tidak hanya berakarir dibagian akuntansi saja terdapat keinginan lain dari mahasiswa dalam berkarir yang dapat mengasilkan lebih besar dari pada seorang akuntan, sesuai dengan yang diungkapkan Indriani (2014) mahasiswa akuntansi dapat berkarir sebagai wirausaha yang tidak memerlukan sertifikasi kompetensi. Sesuai juga dalam penelitian ini mengenai pernyataan indikator motivasi karir yang menyatakan bahwa dengan sertifikasi kompetensi dapat meningkatkan peluang untuk memperoleh tarif gaiji yang lebih tinggi sebanyak 30 responden menjawab tidak setuju dengan 11 diantaranya merupakan mahasiswa yang telah lulus dan bekerja, sehingga mereka telah merasakan dunia kerja itu sendiri bagaimana.

\section{Pengaruh Motivasi Kualitas terhadap Kelulusan USKAD}

Pada hasil pengujian variabel motivasi kualitas menunjukan nilai signifikan sebesar 0.098 yang berarti $>0.05$. Nilai koefisien regresi negatif sebesar -0.252 . Dengan demikian dapat disimpulkan bahwa motivasi kualitas tidak berpengaruh terhadap tingkat kelulusan uskad pada mahasiswa FEB di UPNVJ.

Penelitian ini tidak konsisten dengan penelitian yang dikemukakan oleh Benny (2006) menunjukan bahwa adanya pengaruh yang signifikan pada motivasi kualitas, serta pada penelitian Indrawati (2009) menemukan hasil pada motivasi kualitas adalah berpengaruh signifikan karena dengan mengikuti sertifikasi seseorang merasa bahwa akan lebih

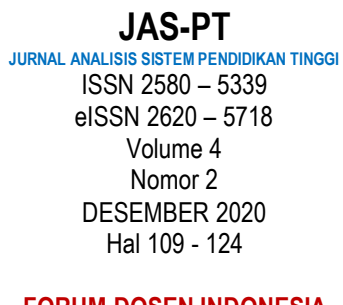

FORUM DOSEN INDONESIA 
berkualitas. dengan adanya rasa jika seseorang merasa jika dengan mengikuti sertifikasi akan membuat seseorang berkualitas, maka ia akan berusaha untuk mencapai keinginannya (Sudaryono, 2005)

Pada penelitian ini motivasi kualitas tidak berpengaruh terhadap kelulusan uskad hal ini dikarenakan sebanyak 80 orang yang mengikuti uskad 30 mahasiswa tidak setuju dengan 11 diantaranya tidak lulus pada ujian uskad dan sebanyak 4 orang diantaranya sudah terjun dalam dunia pekerjaan menyatakan tidak setuju bahwa dengan mengikuti uskad dapat membantu mengembangkan kualitas mahasiswa dalam bidang akuntansi. Serta uskad bukan penilaian bahwa seseorang dapat menganalisa laporan keuangan dengan baik atau dapat meningkatkan pengetahuan akuntansi karena bisa di peroleh selain mengikuti uskad.

\section{Pengaruh Motivasi Belajar terhadap Kelulusan USKAD}

Pada hasil pengujian variabel motivasi belajar menunjukan nilai signifikan sebesar 0.398 yang berarti $>0.05$. Nilai koefisien regresi positif sebesar 0.118 . Dengan demikian dapat disimpulkan bahwa motivasi belajar tidak berpengaruh terhadap tingkat kelulusan uskad pada mahasiswa FEB di UPNVJ. Pada penelitian yang telah dilakukan tidak sejalan dengan penelitian yang dijelaskan oleh Yusuf (2009) dengan mengemukakan hasil terdapatnya pengaruh positif anatara motivasi belajar dengan hasil belajar yang artinya dengan peningkatan motivasi belajar akan mampu mempengaruhi hasil belajar. Tetapi berbeda pada penelitian yang dikemukakan oleh Astasari (2018) penelitiannya mendukung penelitian ini ia mengemukakan bahwa motivasi belajar tidak terdapat pengaruh terhadap minat mahasiswa untuk berkarir sebagai seorang akuntan.

Pada teori atribusi yang dikemukakan oleh Fritz Heider (1958) yang menyatakan mengenai perilaku seseorang dapat dipengaruhi oleh faktor internal dan eksternal. Menurut Ivancevich, John, Robert (2007) teori atribusi merupakan suatu proses dimana individu berusaha menjelaskan alasan dari suatu peristiwa. Guna menyeimbangkan perilaku agar merasa lebih nyaman dalam berinteraksi dengan lingkungan serta mencocokan dengan lingkungan sekitar. Penentuan faktor internal dan eksternal di pengaruhi oleh tiga hal yaitu: 1) Konsensus - tindakan dimana seorang individu menunjukan perilaku dalam menghadapi situasi dan merespon yang sama seperti penanggap, 2) Konsistensi - merupakan tindakan dimana seorang individu menunjukan perilaku yang sama, 3) Keunikan atau kekhususan - merupakan tindakan dimana seorang individu berperilaku yang sama pada waktu yang berbeda atau hanya pada situasi ini saja. Penelitian yang dilakukan oleh Ayu, Putra dan Trisna (2019) yang meneliti hubungan faktor-faktor motivasi dan minat yang mempengaruhi mahasiswa dalam mengikuti Brevet Pajak faktor internal diwakili oleh pengetahuan perpajakan, motivasi kualitas, motivasi karir sedangkan faktor eksternal diwakili oleh motivasi ekonomi. Pada penelitian Rahmawati dan Ervanto (2017) menemukan hasil bahwa pembelajaran menggunakan stadi kasus mempermudah mahasiswa memahami materi metode pembelajaran studi kasus ini dapat dikelompokan sebagai faktor eksternal.

Dalam penelitian ini motivasi belajar tidak memiliki pengaruh terhadap tingkat kelulusan Berdasarkan hasil deskriptif statistik menyatakan bahwa motivasi belajar tinggi tetapi

JAS-PT

JURNAL ANALISIS SISTEM PENDIDIKAN TINGG ISSN $2580-5339$ eISSN $2620-5718$

Volume 4

Nomor 2

DESEMBER 2020

Hal $109-124$

FORUM DOSEN INDONESIA pada hasilnya tidak memiliki pengaruh. Hal ini dikarenakan adanya pengaruh internal dimana belajar pada mahasiswa tinggi tapi penggunaan metode dalam belajar kurang efektif, sehingga mempengaruhi hasil pada saat melaksanakan ujian sertifikasi akuntansi dasar. Pada penelitian menganai indikator meluangkan waktu untuk belajar dan mengorbankan apapun untuk kelancaran dalam belajar sebanyak 34 responden tidak menyetujui hal tersebut yang artinya masih banyak mahasiswa yang tidak meluangkan waktu untuk belajar. 


\section{Pengaruh Metode Pembelajaran terhadap Kelulusan USKAD}

Pada hasil pengujian variabel motivasi karir menunjukan nilai signifikan sebesar 0.047 yang berarti $<0.05$. Nilai koefisien regresi positif sebesar 0.189 . Dengan demikian dapat disimpulkan bahwa motivasi metode pembelajaran berpengaruh terhadap tingkat kelulusan uskad pada mahasiswa FEB di UPNVJ.

Penelitian ini sesuai dengan peneliitian yang dikemukakan oleh Weil, (2004) menyatakan bahwa proses pembelajaran dengan studi kasus memudahkan mahasiswa dalam memahami kasus yang ada dan dapat mengembangkannya. Menurut Listiad dan Imelda, (2010) menemukan hasil bahwa pada model pembelajaran langsung cukup efektif ini terbukti bahwa $75 \%$ siswa dapat menuntaskan kompetensi akuntansi sesuai capaian yang diharpakan sekolah. Sehingga dapat disimpulkan bahwa pada metode pembelajaran baik dengan studi kasus ataupun dengan pembelajaran secara langsung yang telah dilakukan FEB prodi Akuntansi S1 seperti diskusi kelompok, pembelajaran berbasis masalah, dan diskusi tanya jawab dapat membantu mahasiswa dalam memahami dam menyelesaikan persoalan yang diberikan pada saat uskad.

\section{PENUTUP}

Beberapa kesimpulan penelitian ini adalah sebagai berikut Motivasi Prestasi tidak berbepangruh secara signifikan terhadap tingkat kelulusan uskad pada mahasiswa FEB UPNVJ Prodi Akuntansi S1. Motivasi Karir tidak berbepangruh secara signifikan terhadap tingkat kelulusan uskad pada mahasiswa FEB UPNVJ Prodi Akuntansi S1. Motivasi Kualitas berbepangruh secara signifikan terhadap tingkat kelulusan uskad pada mahasiswa FEB UPNVJ Prodi Akuntansi S1. Motivasi Belajar tidak berbepangruh secara signifikan terhadap tingkat kelulusan uskad pada mahasiswa FEB UPNVJ Prodi Akuntansi S1. Metode Pembelajaran berpengaruh secara signifikan terhadap tingkat kelulusan uskad pada mahasiswa FEB UPNVJ Prodi Akuntansi S1.

Peneliti selanjutnya diharapkan bisa menambah variabel - variabel lain yang diduga berpengaruh terhadap tingkat kelulusan USKAD serta dapat menambah teknik dalam mengumpulkan data seperti wawancara dan Peneliti selanjutnya diharapkan dapat memperluas jumlah sampel agar dapat memperoleh hasil yang lebih bervariasi.

\section{DAFTAR PUSTAKA}

Abidin, A. Z. and Ervanto, adi darmawan (2015) 'Pengaruh Motivasi Terhadap Minat Mahasiswa Akuntansi Mengikuti Ujian Certified Public Accountant ( Cpa )', Jaffa, 03(1), pp. 55-68. Available at: http://journal.trunojoyo.ac.id/jaffa/article/view/957.

Ade Puspito, Rudi Kusubagio, dan N. Q. (2017) 'Pengaruh Kecerdasan Emosional, Motivasi Belajar, Dan Kecerdasan Spiritual Terhadap Pemahaman Mata Kuliah Akuntansi Keperilakuan', Sains Manajemen Dan Bisnis Indonesia, 7(1), pp. 96113.

Agninsyah, R. (2018) 'Mahasiswa Akuntansi Mengikuti Sertifikasi Association Of Chartered Certified Accountans ( Acca )'. Yogyakarta: Uin Yogyakarta.

Astasari, A. (2018) 'Analisis Faktor-Faktor yang Mempengaruhi Minat Mahasiswa Akuntansi Memilih Berkarir Sebagai Akuntan Publik (Studi pada Mahasiswa Jurusan Akuntansi di Universitas Islam Indonesia Daerah Istimewa Yogyakarta)'. doi: 10.1017/CBO9781107415324.004.

Aydın, F. and Coskun, M. (2011) 'Secondary School Students ' "Achievement Motivation " towards Geography Lessons', Archieves of Applied Science Research, 3(2), pp. $121-134$.

\footnotetext{
JAS-PT

JURNAL ANALISIS SISTEM PENDIDIKAN TINGGI ISSN $2580-5339$ elSSN $2620-5718$ Volume 4 Nomor 2 DESEMBER 2020 Hal $109-124$

FORUM DOSEN INDONESIA
} 
Benny (2006) 'Akuntansi Untuk Mengikuti Pendidikan Profesi Akuntansi ( PPAk )'. Padang: Simposium Nasional Akuntansi IX, pp. 1-73.

Boyce, G. et al. (2001) 'Fostering deep and elaborative learning and generic (soft) skill development: The strategic use of case studies in accounting education', International Journal of Phytoremediation, 21(1), pp. 37-60. doi: 10.1080/09639280121889.

Campbell, R. L. and Bickhard, M. H. (1992) 'Types of constraints on development: An interactivist approach', Developmental Review, 12(3), pp. 311-338. doi: 10.1016/0273-2297(92)90012-Q.

Dewanti, P. W. (2016) 'Analisis Kesiapan Sertifikasi Kompetensi Pada Sub Kompetensi Kemampuan Menyusun Laporan Keuangan Sesuai Dengan Standar Akuntansi Keuangan ( Sak ) Bagi Mahasiswa Prodi Akuntansi D3 Fakultas Ekonomi ( Fe ) Uny Berdasarkan Sertifikasi Keahlian Akuntansi Dasar', XIV(2), pp. 117-126.

Dyastari, N. and Yadnyana, I. (2016) 'Pengaruh Motivasi Pada Minat Mahasiswa Non Akuntansi Untuk Mengikuti Pendidikan Profesi Akuntansi', E-Jurnal Akuntansi, 16(1), pp. 333-361.

Fernandez, A. R., Studnek, J. R. and Margolis, G. S. (2008) 'Estimating the probability of passing the national paramedic certification examination', Academic Emergency Medicine, 15(3), pp. 258-264. doi: 10.1111/j.1553-2712.2008.00062.x.

Gesinde, A. M. (2000) 'Motivation. In Z.A.A. Omideyi (Ed.)'. Ibadan: Kanead, pp. 12-26.

Ghozali, I. (2018) 'Aplikasi Analisis Multivariate Dengan Program IBM SPSS 25', in. Semarang: Badan Penerbit Universitas Diponegoro.

Hariyani, M. (2013) 'Faktor-Faktor yang mempengaruhi Minat Mahasiswa Akuntansi Mengikuti Pendidikan Profesi Akuntansi (PPAk)', Journal of Chemical Information and Modeling, 53(9), pp. 1689-1699. doi: 10.1017/CB09781107415324.004.

Hassall, T., Lewis, S. and Broadbent, M. (1998) 'Teaching and learning using case studies: A teaching note', International Journal of Phytoremediation, 21(1), pp. 325-334. doi: 10.1080/096392898331108.

Husein, U. (2011) 'Metode Penelitian Untuk Skripsi dan Tesis Bisnis', in edisi 11. 11th edn. Jakarta: PT Raja Grafindo Persada.

Iman, W. (2014) 'Peningkatan Hasil Belajar Siswa Kompetensi Dasar Persamaan Akuntansi Melalui Pendekatan Pendidikan Karakter Menggunakan Metode Group Investigation', Dinamika Pendidikan, 9(2), pp. 121-129. doi: 10.15294/dp.v9i2.4888.

Iriyadi, I., Tartilla, N., \& Gusdiani, R. (2020, May). The Effect of Tax Planning and Use of Assets on Profitability with Good Corporate Governance as a Moderating Variable. In 2nd International Seminar on Business, Economics, Social Science and Technology (ISBEST 2019) (pp. 220-227). Atlantis Press.

Iqbal, J. (2017) 'Pengaruh Motivasi Terhadap Minat Mahasiswa Akuntansi Politeknik Jambi untuk Mengikuti Pendidikan Profesi Akuntansi (PPAK)', Jurnal SAINSTECH Politeknik Indonusa Surakarta, 1(7), pp. 10-19.

Istanto, F. (2010) 'Analisis Pengaruh Pengetahuan Tentang Pajak, Kualitas Pelayanan Pajak, Ketegasan Sanksi Perpajakan dan Tingkat Pendidikan Terhadap Motivasi Wajib Pajak Dalam Membayar Pajak', Skripsi, pp. 1-115.

JAS-PT

JURNAL ANALISIS SISTEM PENDIDIKAN TINGG ISSN $2580-5339$ eISSN $2620-5718$

Volume 4

Nomor 2

DESEMBER 2020

Hal $109-124$
Ivancevich, John M., Robert K, M. T. M. R. K. (2007) 'Perilaku dan Manajemen Organisasi (Edisi Ketujuh).', in Salemba Empat. Empat. Jakarta.

Johnstone, K. M. and Biggs, S. F. (1998) 'Problem-based learning: Introduction, analysis, and accounting curricula implications', Journal of Accounting Education, 16(3-4), pp. 407-427. doi: 10.1016/s0748-5751(98)00026-8. 
Kusuma, G. P. (2011) Pengaruh Kompetensi dan Pengembangan Karir Terhadap Minat Mahasiswa Untuk Mengikuti Pendidikan Profesi Akuntansi (PPA) Studi Empiris Pada Universitas Diponegoro dan Unisbank Semarang.

Lestari, A., Yasa, I. N. P. and Herawati, N. T. (2019) 'Motivasi Karir dan Motivasi Kualitas terhadap Minat Mahasiswa Jurusan Akuntansi Program S1 Universitas Pendidikan Genesha untuk Mengikuti Brevet Pajak', Jurnal IImiah Mahasiswa Akuntansi, 10(2), pp. 183-194.

Listiad, A. and Imelda, F. (2010) 'Penerapan Model Pembelajaran Langsung Untuk Meningkatkan Hasil Belajar Akuntansi Siswa Kelas Xi Ips 2 Pada Kompetensi Dasar Penyusunan Laporan Keuangan Perusahaan Jasa Di Sma Negeri 18 Surabaya', Journal of Accounting Education.

Novita Indrawati (2009) 'Motivasi Dan Minat Mahasiswa Untuk Mengikuti Pendidikan Profesi Akuntansi (PPAk)', Pekbis Jurnal, 1(2), pp. 124-130.

Owusu, G. M. Y. et al. (2018) 'What explains student's intentions to pursue a certified professional accountancy qualification?', Meditari Accountancy Research, 26(2), pp. 284-304. doi: 10.1108/MEDAR-06-2016-0065.

Pamungkas, B., Flassy, D. A., Yudanto, S., Rachman, H. A., Rahayu, S., Komarudin, S., \& Setijono, H. (2018). Accrual-based accounting implementation in Indonesian's local governments compared to other countries' experiences. Man in India, 98(1), 1-23.

Pendidikan, S. et al. (2016) 'Hasil Belajar Siswa Kelas V Sd Negeri Kabupaten Wonosobo'.

Pratiwi, R. H. (2017) 'Pengujian Theory Of Planned Behavior Dan Motivasi Terhadap Minat Mahasiswa Akuntansi Memperoleh Sertifikasi Chartered Accountant (CA)'. Surakarta: Skripsi IAIN Surakarta.

Purba, J. H. V. (2001). Keragaan Kelapa Sawit Indonesia Ditinjau dari Jenis Pengusahaan dan Wilayah Produksi (Doctoral dissertation, Doctoral dissertation, Tesis Magister Sains. Program Pascasarjana, Institut Pertanian Bogor, Bogor).

Rahmawati, E. and Ervanto, A. D. (2017) 'Pembelajaran Mata Kuliah Perpajakan Berbasis Kasus : Bukti Empiris Dan Survei', Neo-Bis, 11(2), pp. 102-120.

Sanjaya, W. (2010) 'Strategi Pembelajaran Berorientasi Standar Pendidikan', in Kencana (ed.). jakarta, p. 109.

Sarjono, B. (2011) 'Faktor- Faktor Yang Mempengaruhi Minat Mengikuti Program Pendidikan Brevet Pajak Di Stie Perbanas Surabaya', The Indonesian Accounting Review, 1(01), p. 1. doi: 10.14414/tiar.v1i01.428.

Solikhah, B. (2014) 'An Application of Theory of Planned Behavior towards CPA Career in Indonesia', Procedia - Social and Behavioral Sciences. Elsevier B.V., 164(August), pp. 397-402. doi: 10.1016/j.sbspro.2014.11.094.

Sudaryono, E. A., P, A. T. and Setiawan, D. (2005) 'Minat Mahasiswa Akuntansi dalam Mengikuti Pendidikan Profesi Akuntansi ( Ppa ) ditinjau dari Gender dan Status Akreditasi Program Studi', Jurnal Akuntansi dan Investasi, 6(1), pp. 114-128.

Suherman, A. (2010) 'Pengaruh Persepsi Mahasiswa Akuntansi Tentang Pajak Dan Brevet Pajak Terhadap Minat Berprofesi Dibidang Perpajakan', (2007), pp. 11641175.

Ulfah, R., Amril Jaharadak, A. and Khatibi, A. A. (2019) 'Motivational factors influencing MSU accounting students to become a certified public accountant (CPA)', Management Science Letters, 9(10), pp. 1675-1684. doi: 10.5267/j.msl.2019.5.020.

Wardhani, erlita cahya widha (2017) 'Peningkatan Kemampuan Menulis Teks Biografi Menggunakan Metode Pengajaran Langsung pada Siswa Kelas X SMA Negeri 3

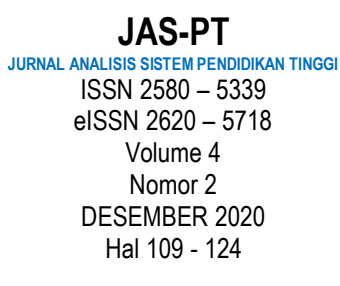

FORUM DOSEN INDONESIA 
Purworejo Tahun Pelajaran 2016/2017', Skripsi, pp. 1-159. Available at: http://repository.umpwr.ac.id:8080/bitstream/handle/123456789/1254/132110098 -Cahya Widha Wardhani.pdf? sequence=1\&isAllowed=y.

Weil, S., Oyelere, P. and Rainsbury, E. (2004) 'The usefulness of case studies in developing core competencies in a professional accounting programme: A New Zealand study', Accounting Education, 13(2), pp. 139-169. doi: 10.1080/09639280410001676602.

Widyastuti, S.W, Suryaningsum S, dan J. K. (2004) 'pengaruh-motivasi-terhadap-minatmahasiswa-akuntansi-untuk-mengikuti-pendidikan-profesi-akuntansi-ppak'.

Denpasar-Bali: SNA VII Denpasar-Bali, 2-3 Desember.

JAS-PT

JURNAL ANALISIS SISTEM PENDIDIKAN TINGG

ISSN $2580-5339$

eISSN $2620-5718$

Volume 4

Nomor 2

DESEMBER 2020

Hal 109 - 124

FORUM DOSEN INDONESIA 